The intergovernmental dimension of multi-commons management MODERNISATION AND REFORM OF DUTCH WATERBOARDS: RESILIENCE OR CHANGE?

\author{
Theo A.J. Toonen \\ Gerrit S.A. Dijkstra \\ Frits van der Meer \\ (C) Department of Public Administration \\ Leiden University
}

Paper prepared for WOW3: The Third Pent annual WORKSHOP ON THE WORKSHOP "Building Social Capital and Self-Governing Capabilities in Diverse Societies", Conference, Workshop in Political Theory and Policy Analysis (Dir: Elinor Ostrom, Vincent Ostrom), Indiana University, Bloomington, June 2-6, 2004

Leiden, May 2004

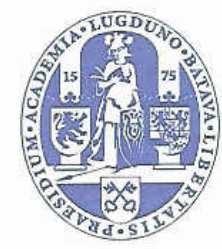


The intergovernmental dimension of multi-commons management

\title{
MODERNISATION AND REFORM OF DUTCH WATERBOARDS: RESILIENCE OR CHANGE?
}

\author{
Theo A.J. Toonen \\ Gerrit S.A. Dijkstra \\ Frits van der Meer \\ Department of Public Administration \\ Leiden University
}

\section{Introduction}

Given its geographical conditions water management has always been a vital precondition of life in the Netherlands. This in particular pertains to the issues of water quantity (waterkwantiteit), water quality (waterkwaliteit) and water containment (waterkering). Water and water management in all its manifestations certainly in the Netherlands may be considered as 'Commons' in more than one way.

Commons consists of natural (water, fisheries, and nature areas) or cultural (manmade) resources (dykes; polders, markets; institutional designs, institutions; safety, protection, trust). Specific institutional arrangements - sometimes 'commons' in themselves - are needed to guarantee the durability and sustainability of the use of these resources. As collectively used goods they belong to everybody and at the same time to nobody. Exhaustion, negligence and overuse are permanent dangers given the nature of the character of the commons. The creeping erosion of the resilience of common pool resources and of common pool resource (CPR) governance and management is nevertheless not a mechanical and inevitable process. There is room for vision and choice. The human-environment interaction is part of the Commons-problem. This is open for reflection and deliberation and can be influenced and changed through the choice of behavioural strategies and institutional arrangements. Put differently: the 
organisation and design of the regime of governance is an essential part of the Commonsproblem and the way to tackle it. Current international insights in governing the Commons point to the particular importance of community based governance ${ }^{1}$.

The Dutch Water Boards are often presented as prime examples of a form of community based common pool resource management. Given its resilience and its community based character in dealing with water management issues and in the light of emerging theoretical and empirical insights in CPR governance, the water boards may be hailed as a Golden Formula. Yet that golden formula - at least at face value and in its traditional institutional format - is severely under threat due to a historically unprecedented scale enlargement in the Dutch water board system over the past decade. That threat and the way to possibly answer it is core topic of this paper.

In this paper we discuss the historical development of the water boards as a form of community based common pool resource (CPR) governance and management. The water boards have evolved over the last millennium and over time adapted to the particular needs of the times involved. Those developments were gradual and evolutionary in most periods. However at the moment the water board system is subject to some profound changes due to international ecological, Euro-political, economic and technological developments. Over the last decennia the number of water boards in the Netherlands has been reduced from around 2500 to around 26. Coinciding with these profound merger programs, the overall system of governance operated by the water boards and their relationship to other governments in the Dutch state system changed in the last decades. More specifically there is a heavier emphasis on a heteronymous style of operations including a less direct involvement of citizens. At the same time water boards are more integrated into the system of intergovernmental relations and network management. Given these developments, the question may be raided whether the water boards of today are still the resilient institutions adapting to changing circumstances. Or do the water

\footnotetext{
${ }^{1}$ Th. Dietz, E. Ostrom, Paul C. Stern, The Struggle to Govern the Commons, in: Science, December 2003: 1909 en 1910
} 
boards of today only in name resemble the CPR management form of old, having lost their small scale community based character?

In this paper we do examine this claim of the erosion of the community based character of the Dutch water boards as a CPR. We will first outline our theoretical frame of reference (paragraph 2). Next we will describe the historical development of the Dutch water board system, with an emphasis on the developments since the end of the $18^{\text {th }}$ century when the system took on its present institutional form, which underwent such drastic reforms since the end of the $20^{\text {th }}$ century. We will briefly present the challenges the late $20^{\text {th }}$ century water board system faced as a background to the reforms (paragraph 3). We try to assess whether the institutional nature of the water board system has changed seen as a form of CPR management (paragraph 4). We wrap up with a brief conclusion (paragraph 5).

\section{Analytical Framework: Water boards as CPR management}

The Dutch water boards are a unique institution with a long historical record. This venerable past commands on the one hand respect in political and social debates: 'they've existed for so long and have proven themselves extensively...' But history can also be used against them: 'They've existed for so long, isn't this the time to...' And of course every history has its own stories of success and failure, of which the latter category is known to remain longer on the short term than the former.

As a unique Dutch institution for the management of water quality, water quantity and water containment, water boards are confronted with institutional and administrative problems which are - nationally and internationally - not unique at all and which are not limited to contemporary water management. They are by definition part of a complex, layered, manifold and - in the eyes of some - sometimes inefficient administrative and governmental organisation and arrangement. These are issues that a lot of commons - all

over the world - share or at least have 'in common' with each other, sometimes with all kinds of supposed or real negative side effects as a consequence. Administrative streamlining, however, in CPR research is hardly considered a goal on its own: 
'Simple strategies for governing the world's resources that rely exclusively on imposed markets or one-level, centralized command and control and that eliminate apparent redundancies in the name of efficiency have been tried and have failed. Catastrophic failures often have resulted when central governments have exerted sole authority over resources.' 2

A robust - resilient - administrative organisation for the commons - like water management and other joint consumption goods - requires attention for diversity, checks and balances, self-regulation, conflicts and conflict management. 'One form does not fit $a l l^{3}$. Tailor made solutions are deemed necessary and possible in CPR-management.

\section{Efficiency}

Recent discussions about the function and organization of water boards in the Dutch context are marked by the media in terms of efficiency and administrative streamlining and rationalisation. Kroes and Van Rooy, for example, argue: 'nowadays, four billion euro is spent on water management on a yearly basis. (...) Just the collection of the various taxes costs the taxpayer 230 million euro a year. Thus it seems more sensible to search for more effectiveness and efficiency in water management (...) The government however focuses primarily on the continued existence of the water boards, whose origins lies in the Middle Ages, in their current form and is dragging financial arguments by the head. The 'elections that cost tens of millions' are criticized. Democracy isn't considered to deliver any (added) value for the water boards. Between the lines these critics show to be more charmed by a model in which '... the autonomy of water boards will be (severely) limited' and for example be turned in state run executive organisations. ${ }^{4}$

\footnotetext{
${ }^{2}$ Dietz, Ostrom, Stern, op. cit, 2003: 1910

${ }^{3}$ P.C Stern, Th. Dietz, N. Dolsak, E. Ostrom, S. Stovich, Knowledge and Questions after 15 Years of Research, in: National Research Council, The Drama of the Commons. Committee on the Human Dimensions of Global Change. E. Ostrom, T. Dietz, N. Dolsak, P. C. Stern, S. Stovich, E. U. Weber (eds), National Academy Press, Washington DC, 2002:456

${ }^{4}$ Neelie Kroes, Peter van Rooy, Kabinet houdt water kostbaar, Volksrant - Forum, 17 februari 2004:13
} 
The deputy minister responsible for the water board system replies immediately: "Water management cannot be more efficient' and ' let it the discussions about the organisational structures finally end because there is after all a more important task: given the many challenges water management should be on speed by $2015^{\prime}$.

Indeed: 'a good water management is of existential importance to the Netherlands.' ${ }^{6}$ This is the point of departure the opponents share. As modern international research in CPR management reveals, putting this question in terms of efficiency would take us down the wrong route in dealing with the subject. Viewed from the perspective of modern institutional research regarding the development of administrative structures like the water boards, putting emphasise on efficiency in relation to the desired administrative water management arrangements in the Netherlands, will easily lead to 'errors of the third type': the right solutions for the wrong problem. Efficiency is important as a standard for any administrative arrangement, but it does not mean much else than to realise prescribed goals with a minimum of means, or to realise with a given stock of means, a maximum of result (production) within given constraints and preconditions.

\section{Governance}

For sure, efficient, purposeful and effective management is an important administrative quality. As important -if not more important- however, is the issue of governance: how does one determine the (for an efficient management) 'given goals' or 'given means' or 'given preconditions'. This raises the question how many resources one would like to place at the disposal of the organisation, or which preconditions one wishes to accept as a 'bottom line' for the administrative and policy dimensions of water quality management. In modern management jargon: besides 'doing the things right', we should be 'doing the right things'. How does one legitimise - justify and account - oneself for the choices made?

\footnotetext{
${ }^{5}$ Melanie Schultz van Haegen, Waterbeheer kan niet efficiënter, Volkskrant - Forum, 19 februari 2004:13 ${ }^{6}$ cf Kroes, Van Rooy, op cit., and Dutch Government White Paper: Regeringsstandpunt IBO bekostiging waterbeheer (DGW/BI 2004/303): 6 (italics; TT et al)
} 
This governance issue should be clearly distinguished from the management (efficiency) dimension when analyzing the position of the water boards. However, there is yet an additional point to be taken into consideration. CPR management implies 3 simultaneous 'worlds of action'. 'Like management, also governance and the introduction of goals, legitimised means and constraints is not a casual and abstract matter happening in an institutional vacuum. Establishing goals in an interactive network setting is a strategic activity. With that, one is under strong influences of the behaviour of others. Positioning goals, particularly in the form of 'revealed (as over and against stated) preference', is often characterised by 'hold-out' and 'free-rider' behaviour. Over and over again it seems 'rational' and 'efficient' to leave the initiative in collective matters to others. The wellknown paradoxical, but logical consequence of this is, that under the presupposition of an 'efficient and rational organisational structure' none of the parties involved takes the initiative and the communal - the collective - interests are not looked after for and by anyone.

This applies ipso facto also to abstaining from taking initiatives in order to sustain or create collective provisions, which also may threaten on the long term the existence of common pool resources. For the inhabitants of urban regions in the Netherlands, for example, the water board is a largely unknown administrative organisation. For them, 'dry feet' are a fact of life and more or less taken for granted. Research shows that in the Netherlands the chance of a flood disaster is collectively and systematically underestimated $^{8}$. It is of importance that an organisation is not only practically in charge of combating threats regarding water management issues but also is increasing the awareness of these issues in society, even in times when society is not paying too much public and political attention to this vital 'common good'.

\section{Resilience}

In short, the argument above implies that the discussions about the raison d'etre of the water boards and the 'existential' nature of the water management system they stand for shouldn't be held so much in terms of efficiency, but in terms of durability, tenability,

\footnotetext{
${ }^{7}$ L. Kiser, E. Ostrom, The Three Worlds of Action, in: E Ostrom (ed), Strategies of Political Inquiry, Sage Beverly hills, 1982:179-222

${ }^{8}$ for example: Leidsch Dagblad, 3-11-2004:3
} 
resilience and adaptability. Around 35 years ago, Gareth Hardin wrote his seminal article in 'Science'. ${ }^{9}$ He spoke of 'The Tragedy of the Commons'. 'Commons' are natural and cultural '(man-made') resources (like - also - polders, dikes, sluices, dams, irrigation systems and water outlets) which, being collective consumer goods, could be available to everyone in principle against marginal individual instead of integral collective or social costs. For that reason the demand exceeds the supply by definition. Stretching demand, exhaustion and neglect of communal consumer goods are permanent threats, unless one arms oneself against it institutionally. The strength and resilience of protection and preserving strategies are high on the agenda of CPR-management.

In the presence of a foreseeable large-scale technological and demographical development, Hardin saw for the management of the Commons internationally and in policy terms a way out in a forced population policy, concentrating on birth control, or strong repressive government action. Concerning the latter he saw only two institutional options: general centralisation of the decision-making and the management of the commons, or the assigning of (maintainable) property rights of communal consumer goods to privately-owned market parties. Hardin thereby limited the strategic administrative options in the social institutional control of the Commons to centralised nationalisation on the one hand or radical privatising on the other.

In December of 2003 the editors of Science drew up the balance of 35 years research on the Commons. ${ }^{10}$ The article of Hardin has developed into a classic when thinking about durability and institutional development in controlling the Commons, like water quality and water quantity (among many more naturally). The research has brought to light a lot of failing structures, which sustain the realistic nature of Hardin's model, but also a large amount of effective, legitimised and durable forms of common pool resource management.

\footnotetext{
${ }^{9}$ Gareth Hardin, The Tragedy of the Commons, in: Science, 162, 1968: 1243-1248

${ }^{10}$ Science, vol 302, 12 december 2003:1861-1930
} 
Market economics in controlling the commons turns out to be, more often than not, impossible because of the (natural) monopoly-like nature of the commons. ${ }^{11}$ Centralised institutions turn out to be a useful alternative only, when one is willing to set up a quite authoritarian and expensive maintenance-structure. ${ }^{12}$

'Whether enforcement mechanisms are formal or informal, those who impose them must be seen as effective and legitimate by resource users or resistance and evasion overwhelm the commons strategy.

Much environmental regulation in complex societies has been 'command and control'. Governments require or prohibit specific actions or technologies, with fines or jail terms possible for rule breakers. If sufficient resources are made available for monitoring and enforcement, such approaches are effective. But when governments lack the will or the resources to protect "protected areas", when major environmental damage comes from hard-to-detect "non-point sources", and when the need is to encourage innovation in behaviours or technologies rather than to require or prohibit familiar ones, command and control approaches are less effective. They are economically inefficient in many circumstances.

Contemporary understanding of the management of the international commons therefore points mainly to the great significance of community based governance. ${ }^{13}$

'Delegating authority to (...) ministries does not always resolve conflicts satisfactorily' (...) 'Too many strategies for governance of local commons are designed in capital cities or by donor agencies, in ignorance of the state of the science and local conditions. The results are often tragic'

\footnotetext{
${ }^{11}$ Th. Dietz, E. Ostrom, Paul C. Stern, The Struggle to Govern the Commons, in: Science, December 2003: 1910

${ }^{12}$ Dietz, Ostrom, Stern, op. cit., Science, 2003:1909

${ }^{13}$ Ibid: 1909 en 1910
} 
In international institutional research the norms and standards for 'good governance' of the commons show that, nowadays especially, the institutional design should be directed at the development of cooperation, trust and the growing of social capital ${ }^{14}$ :

'Collective resource management programs that seek to build trust, develop new norms, and help form groups have become increasingly common, and such programs are variously described by the terms community-, participatory-, joint-, decentralized-, and co-management'.

\section{Constitutional position}

In the perspective of the 3 Worlds of Action, Dutch water boards have a 'constitutional value' or a 'constitutional quality' to them. ${ }^{15}$ In the Dutch context this is easily interpreted as to say that the special position of the water board lies in the fact that it has a formal constitutional position, thus easily turning a substantial or functional debate on institutional quality into a formal argument of traditional constitutional law and effective legal position. The water boards are a typical combination of functional and territorial decentralisation. They are a form of independent decentralised government, which within a given territory are responsible for a specific task. The water board has the status of a government which is authorized to take binding decisions, including the levy of taxes, within the domain that was assigned to it - and was given concrete form by communication and coordination mechanisms back and forth with other governments. The legitimisation is founded by the usual legal imbedding of the Rechtstaat and separation of powers with respect to the other, general purpose governments municipalities, provinces, national government - as well as on a sort of categorical or functional issue-democracy. Within that domain, the parties - 'interests' - directly concerned are being involved in the decision-making about the governance of the water board and the implementation of policy. Within the overall intergovernmental system his functional interest group-democracy operates in addition to - not as a replacement of the 'general democracy' of the state, provinces and municipalities.

\footnotetext{
${ }^{14}$ Jules Pretty, Social Capital and the Collective Management of Resources, in: Science, vol 302, 12 december 2003:1913

${ }^{15}$ Bestuursschouw, op cit, 2000:40
} 
International research, suggests the importance not to argue from the institutional history and the tradition of the water boards alone, but to include the contemporary administrative and institutional functions they have and may have in the Dutch context and institutional development of CPR (water) management. This function is not - at least not exclusively - determined by (constitutional) law. On the contrary: the constitutional legal framework and juridical set of instruments may rather be seen as the outcome and the manifestation than as the origin of the institutional position and quality which the water board represent in the Dutch situation as administrative institute for CPRmanagement. We therefore favour an approach in which the legal framework, as well as the administrative, organisational and policy dimensions, is being examined regarding the degree to which this framework enables and stimulates the water boards to accomplish their task as CPR-manager of a - for the Dutch society - pivotal responsibility. To be included in the (written) Constitution as a relatively independent ("autonomous") government is a logical outcome of a historical trajectory, but this does not of an in itself provide a solid basis for understanding water boards as a (relatively) independent ${ }^{16}$ institution for common pool resource management.

\section{CPR governance}

By recognizing the water boards as separate governmental unit, the Dutch constitution provides a guarantee for an institutional, communal and administrative stewardship for water management that is dedicated to quality-care in terms of '..." achievement on the ground", namely the sustained protection of significant natural or cultural features' ${ }^{17}$ It is precisely for that reason that the water board has, in the past, gained a socially certified - and constitutionally validated - institutional 'status apart' and has the constitutionally firmly-rooted task to aim its efforts towards the management and stewardship of a - for the Dutch community vital protection-, and safety-infrastructure.

\footnotetext{
${ }^{16}$ Relative independency: an institutional condition which counts for all governments in the Dutch constitution

${ }^{17}$ Heather Millar, Successful Stewardship and Conservation Organisations - Case Studies and Best

Practices, The Leading Edge: Stewardship and Conservation in Canada 2003, British Columbia, 2003:4
} 
Ideally, the water boards are not engaged at length with technical questions of implementation. The water board is a public administrative institution - in contemporary terms: an institution of governance - not an independent executive organisation or a unit for technical policy-implementation. The fact that technical implementation-matters of the organisation internally might have gained the upper hand is a different matter. Externally the core of the institutional strength of the water boards formula that it isolates the 'integral consideration of interests' surrounding the water management somewhat from the regular political and administrative process in the 'general democracy'. Because of the separate imbedding of the water management in water boards an extra investment and extra attention is needed to calculate the water interests against other interests. In the short term, that's not always very useful. It brings forth higher transaction costs, which on a day to day basis are generally experienced as 'inefficiency'. However, that's exactly the purpose of a separated institutionalisation. In the long term - just like, as some people think, the 'very costly' competition on markets - this construction potentially has important benefits, in terms of durability (ability to learn), as well as in terms of governance (transparency) or efficiency (social cost-awareness).

Because of the separate institutionalisation, it is less probable that the political - most of the time barely visible- water management is systematically disadvantaged by, on the short term often changing, other political and socially more visible interests. With the creation of the water boards the realisation came to be that the transaction costs in the intergovernmental communication are visible and not negligible. This offers as such a certain barrier against carelessness and rashness in (communal) use. This is certainly not merely a theoretical phrase. The 'revealed' (as over and against the stated) political priority in the Netherlands - but there are no differences elsewhere - rarely lies, with maintenance. Outside the domain of water management it is for example observed that: "New infrastructure is more "sexy" than utilisation and maintenance', the Ministry of Transport now admits". "Broken locks, signs and highways: the maintenance of Dutch infrastructure seems like that of a third world country" ${ }^{\prime 1}$, recognises the Minister during the autumn-negotiations, while desperately trying to protect her budget. In maintenance lies the essence of common resource management. Because of the separate

${ }^{18}$ Dutch national daily: Volkskrant, Binnenlandpagina, 3-11-2003:2 
institutionalisation of the responsibility for the water management, that management is less dependent on budget cycles and - otherwise quite welcome - electoral dynamics. It can be observed that the water boards in this respect have functioned well over time. The assigning of the tasks of the water boards to bodies of general governance (like the state or provinces) would produce more risks. Bodies of general governance have to weigh off interests in different areas against each other. When, for example, maintenance of dykes in (politically) quiet times gets too little priority because it is politically opportune to invest more money in other areas, this can have catastrophic results.

\section{Organisational learning}

And of course there is always something going awry. The characteristic of catastrophes and crises is that one is never fully able to prevent them. The first reaction after such an event is often denying, rejecting and pointing to others. Often the search for one to bare the guilt takes time and one encounters 'the problem of the many hands' not long after. After a while, it easily turns out that no one was guilty in particular: 'the system is to blame'. Within the system of water management 'one guilty party' however is quickly found. In water management the external justification process is made part of the structure. No matter how small the dyke burst, the media, local authorities and provinces will demand an investigation at once, starting off of course with the relevant water board. This leads to situation in which the outcomes of badly performing water boards are directly visible for everyone. In such a situation there is a large amount of transparency. This vulnerability of the water board is theoretically spoken at the same time a great institutional strength.

\section{Legitimization}

The separated institutionalisation of water boards as (relatively) independent governments in the Dutch context has consequences for its governance structure. It needs a democratic legitimation of its own. Water boards are territory oriented, functional governments within which there are continuous considerations of interests, in the process of giving concrete form to its general - abstract - mission and objective of water containment and controlling water quantity and water quality. Considering the nature and 
the intensity of these interests, it is therefore from a democratic point of view desirable that the parties concerned are tightly involved with the decisions concerning them. The water board structure offers the possibility for this. An independent (administrative) agency ( $Z B O$ in the Dutch debate), in comparison, does not offer those possibilities, unless a structure is chosen which is comparable with the water board. The same argument applies even more strongly to privatisation. To hand the tasks of the water board to for example water companies will lead to a situation in which the parties concerned will not be involved in these tasks anymore, and will probably have no right of say at all.

\section{Community based nature}

The community based nature of water boards and the connection of the governance structure to the local interests and communities affected by the very nature of its activities historically is a key institutional feature of the formal governance structure and institutional tradition of water boards. Traditionally the so called 'Trits', the triplet (trits) Interest-Payment-Right of Say (Belang, Betaling, Zeggenschap) is seen as the basic principle behind the water board governance structure. This 'triplet' implies that those in the community that have a stake (interest) in water management issues in the area are obliged (compulsion) to contribute - financially or otherwise - and have a say in decision making (right of say) of the water board. In the past the 'payment' often occurred in non pecuniary terms by performing water management tasks in nature. Over time the financial approach took over. Water boards calculate the overall costs of their operation in an annual period. They attribute the costs to the functional interests represented in the water management system and levy taxes for various categories of stakeholder groups accordingly. In a sense we can speak of the 'triplet' stake, taxation and representation. The level of representation in the general water board council is linked to the level of taxation and the level of interest.

It is of importance to note that the famous triplet is in fact about the close bond which exists between the parties concerned and the water board governance. Indeed: "no taxation without representation', but also 'no representation without taxation'. Or said in 
a different way: administration close to the people. In the Dutch context it is often brought against this, that also the local and provincial general purpose governments are closer to the people. With regard to water management however, the interests of different citizens vary significantly. Possibly the water boards are mostly known to a lot of people because of the yearly duties. However, this changes for an inhabitant of a big city when a dike bursts. For the agrarian part of the population the case is totally different. Lowering or increasing the water level and changes in the water quality has direct consequences for them and their business operations.

Not the intensity of the interests but also the nature of the interests that are involved within the water board can differ a lot. The one area (and interest) fares well with a high water level, the other with a lower water level. The essence of the water board structure is that these differences in interests are expressed in the institutional design of the water board. The Trits also offers the space to adjust and contextualise the interest representation in the institutional design of the water board council to the spatial, geological and social-economical structure of the own region and the structure of the interests bound to it.

\section{Inclusion}

The bond with the relevant local interest communities in the creation and implementation of policy is not only of importance to legitimise the levy of taxes. More important even than the creed 'no taxation without representation', is the political insight that 'easy implementation tasks' and such do not exist, and certainly not in a complex case like the management of the 'water system' which is not only a technical manner but contains many social, local and regional social-economic considerations and elements. Implementation of water management, given its complex, multi-interest nature brings along considerable 'principal-agency' problems - 'discretion of civil servants'. This provides a second major reason for affected parties - stakeholders - to be represented in the governance structure of water boards, so that the can oversee the executive and operational decision making and implementation. Efficient, effective, legitimate and durable implementation and maintenance - from all sides viewed as the Achilles' heel of the modern governance - may benefit from a form of - so to say: neo corporative - self- 
government. Parties directly concerned are institutionally involved by and addressed on the realisation of the implementation-policy on the field of water management and the administrative choices and responsibilities which there upon inevitably will be discussed.

Indeed: the 'polder model', in the true sense of the word ${ }^{19}$. Once more in history the concept - consensual joined decision making - is currently strongly criticised in the Netherlands. 'Polderen' has become a word - a media nickname - to indicate a dreadful indecisiveness of 'all talk and no action'. Internationally viewed the model is certainly not outdated. Especially in the contemporary management of commons it is paramount to be: 'inducing rule compliance ${ }^{20}$ : to provoke, instead of order, desirable behaviour and civil compliance. As well as legitimisation and social basis such a form of interactive policy-implementation gives prospect to creating co-productions with relevant social actors. These will hopefully position themselves in the context of such a process as shepherds of a general interest, while if they were in another institutional setting they would individually -and each man for him- tend to realise a 'free ride'. Functional representation of and low level thresholds of conflict regulation are therefore an explicit condition for effective and solid CPR-management. It also applies to water boards that:

'Sharp differences in power and in values across interested parties make conflict inherent (...) Indeed, conflict resolution may be as important a motivation for designing resource institutions as is the concern with the resources themselves. People bring varying perspectives, interests, and fundamental philosophies to problems of environmental governance, and their conflicts, if they do not escalate to the point of dysfunction, can spark learning and change'. ${ }^{21}$

\section{Robustness}

From the perspective of CPR-management the internal strength of the water board formula lies in the fact that one tries to bring functional opposites in interests to reconciliation and a consensus in a fundamentally institutionalized way. One supports

\footnotetext{
${ }^{19}$ Frank Hendriks, Theo Toonen (eds), Polder Politics in the Netherlands; Viscous State or Model Polity? Ashgate, London, 2001

${ }^{20}$ Dietz, Ostrom, Stern, op. cit. , Science, 2003:1909.

${ }^{21}$ ibid
} 
this by a form of social participation, not generally ideological, but concrete and aimed on practical confrontation with the ordinary business in the management of water quality and water quantity. This also provides a basis for a 'learning organisation' of water management. To learn means that one may admit ones mistakes openly - if need be institutionally forced to do so - and thus not just selling ones successes. The independent institutionalization of water boards, with its corresponding (interest)community based governance structure brings the in a position in which water boards often have to take the political heat if things go wrong, sometimes - if not often - in cases where the wrongdoing or disaster actually has its cause elsewhere in the chain of water management: a lack of provincial strategic vision and spatial planning which would have to provide the broader policy constraints within which individual water boards as functional governments would have to operate. A lack of direction by national ministries on large scale internationally induced problems of water management - overload as well as shortage (of clean sweet) water - in the European Delta area which the Netherlands in fact constitutes. 'Creative' behaviour by municipalities knowing to bypass zoning principles and, for example, building houses or industry in areas prone to flooding or effectively narrowing riverbeds, thus limiting the possibilities of large scale water control in the case of flooding beyond the limits of individual water boards. A lack of adequate inspection and oversight of water boards and water management by provinces, constitutionally entrusted to them and indispensable to the operation of the intergovernmental system a whole.

However: 'Noblesse obliges'. The constitutionally guaranteed independence of water boards provides them with a special position - and one therefore could say: a special formal responsibility - where the question of answerability is well to be distinguished from accountability. The independent position of water boards offers them the possibility to take an independent stance and publicly defend themselves against unjustified charges, thus contributing to the publicness (transparency) of the system and the political and social debate on water management. Both conditions may be considered, perhaps not sufficient, but at least necessary ingredients of any sustainability and resilience strategy. Also: water boards can't resign just like that and take all the blame themselves, as a result of which further investigation wouldn't be necessary - because the 
blame has been placed - and no one will know what really happened and what could have gone wrong. In that case institutional learning processes are shut out. In many other countries in the third world that's exactly the problem in water management, with the outcomes that are come of it visible daily.

\section{State of affairs}

It is fair to say, that water boards in the Netherlands in the recent times have not exploited or executed these - from a perspective of CPR management seemingly crucial institutional governance functions to the fullest, to put it mildly. General impression is that - over a longer period - the technology and industry of water management has overtaken the governance and public affairs dimension. Water boards, by many, are perceived as rather inward looking, technically and internally operated organisations, specialised in 'water' not for example in 'social capital', 'conflict resolution' or 'social legitimation'. Individual water boards do not tend to view themselves as agents in a larger water management industry, which next to there fellow organisations would also include the 'general purpose governments', market institutions, civil society stewardship organisations, etc. They tend to stress there their 'right to be autonomous' instead.

It is understandable that the reforms - which in general they supported - over the recent years have forced water boards to concentrate on internal matters of organisational strategy and reorganisation. But the question is whether we are dealing with a transitional stage - a brief interlude in a long term institutional development - or

with an episode of structural institutional transformation and change in which the very nature of the reforms will change and erode some of the institutional characteristics of water boards. Particularly characteristics which from a CPR management resilience point of seem to be crucial in constituting the robust and adaptive institution for water management which the water board historically has proven to be.

The enlargement of scale - from more than 2000 to about 26 - implied by the reforms will undoubtedly affect traditional forms of community based governance, functional participation and interest representation. They will place water boards, municipalities, and provinces in a different relationship to each other, not necessarily in terms of the system under which they operate, but at least in terms of positions, power, 
and organisational responsibilities within the system. Due to the complexity and diversity of the newly emerging water board, the Dutch water boards Association already had to let go of the 'Trits' - the historical institutional symbol of there status as independent self government - as there leading institutional design principle in matters of governance. It was once understood as a strict and one to one relationship between interest, contribution and co-determination. Backed up by European principles as 'cost recovery' and 'polluter pays' the principle still plays a role in the institutional debate, but in a way much more loosely coupled to the question of institutional design and representation. In the past it was tried to maintain a strict and in principle individualised, water board by water board tailor-made relationship between the interests, the financial contributions (taxation) and the seats in the general council.

\section{Perennial questions}

Many other features will have to undergo modernisation and reform in a similar fashion. Is this an act of adaptation, innovation and will it therefore turn out to be yet another historical illustration of the seemingly unlimited resilience of water boards and the water board system to strategically adapt to emerging changes in external technological, environmental, economic, ecological and increasingly internationalised challenges which modern water and common pool resource management systems face? Or is it rather 'the end of an institutional history' in that the institutional character of the Dutch water board system is in the process of effectively being transformed into a different institutional species of CPR management from the one it used to be? This then is automatically raising the question if the befamed robustness and resilience of the system is under threat, and if so, how the historically proven resilience of the system of water management in the Netherlands would have to be re-institutionalized?

The final assessment of these big questions is way beyond the scope of this paper. But in order to have a first look at the issues involved, it is clear that at least two steps need to be taken. First, the current reforms and scale enlargement need to be put into an historical perspective of the process of which the current dynamics are the outcome or at least 'point of accumulation'. Secondly, it does not suffice to explore water boards as 
stand alone organisations, but we need to analyse them in the context of the larger governmental and intergovernmental system of which they are effectively part.

\section{The historical development of the Dutch water management system ${ }^{22}$}

From (early) medieval times water management has been an essential task given the marshy geographical conditions the northern and western part of the area what is now called the Netherlands. Water management involved at that time a wide range of activities including making protective measures against incursions of the sea, controlling inland waterways and reclaiming land (the polders). In historiography the beginning of Dutch water management is usually situated at the turn of the first millennium. ${ }^{23}$

Although the availability of early medieval documents is often problematic, the real reason behind this particular starting date has to do with combined physical and societal developments that became really pressing from the $12^{\text {th }}$ century onwards. On the one hand the rise of the sea level that had set in a considerable time before with warming up after the last ice age now became really problematic. The protective sea defences (in particular the dunes) were threatened and areas were inundated. ${ }^{24}$

In combination and even more dangerous were the effects of the colonization of previous wastelands and cultivation of (low laying) wastelands in order to accommodate a rising population. ${ }^{25}$ The effects of the latter can be understood by the fact that increasingly land was being made inhabitable for an expanding population. Cultivating the wasteland implied the creation of drainage systems. Due to the dehydration of the peaty soil the drainage led to a serious settlement of the ground level. ${ }^{26}$ Areas once

\footnotetext{
${ }^{22}$ This part is based on Frits M van der Meer, Water management in the Netherlands in the $19^{\text {th }}$ and $20^{\text {th }}$ centuries in: Jos C.N. Raadschelders, Fresh Water Management as Collective Action in Time: A MultiDimensional and Multi-Level Challenge of Governance in a Multi-Disciplinary Context, IOS press, 2004, forthcoming.

${ }^{23}$ S.J. Fockema Andreae, Studiën over waterschapsgeschiedenis, deel 8, Eduard IJdo, Leiden, 1952, 2-3.

${ }^{24} \mathrm{H}$ van der Linden, Een nieuwe overheidsinstelling. Het waterschap circa 1100-1400, in: Algemene Geschiedenis der Nederlanden, vol. 3, Haarlem: 1982

${ }^{25}$ G.P. van de Ven, Leefbaar laagland. Geschiedenis van de waterbeheersing en landaanwinning in Nederland, Utrecht: 1993, 33; G.J. Borger, Waterschap en fysische omgeving, in Toonen and Raadschelders, 1993, 49-50,

${ }^{26}$ A. Bosch and W van der Ham Twee eeuwen rijkswaterstaat, 1798- 1998, Zaltbommel: 1998, 19
} 
situated above the sea level gradually sank below the water level with as consequences that the vulnerability to floods increased.

In this context the need for collective action in terms an effective design of water management can be understood. From the outset the institutional variation in water management systems was extensive. During the middle ages the Netherlands consisted of a patch work of (semi) independent counties, duchies and the occasional bishopric. There was (excluding present day Belgium) a notional feudal relationship with the Holy Roman Emperor but in practise the influence of the emperor was virtually non-existing.

Already from the outset a wide variety of actors were involved in water management issues. Given water management being a precondition for each community at all levels of society and government it can easily been seen that (groups of) citizens, provincial authorities, local governments and water boards were directly involved and interested in the execution of water management tasks. Regarding the birth of the Dutch water management institutions some questions have been raised concerning the public or private nature of these institutions. Are these institutions from their moment of inception to be considered as a private (citizen) initiative and slowly incorporated in the system of government or as a government institution from the out $\operatorname{start}^{27}$. It is interesting to notice that this question which has repeatedly popped up in the $19^{\text {th }}$ and $20^{\text {th }}$ centuries has not only been academically motivated. The historically founded non governmental dimension of water boards is often used as an argument against a large central but more importantly provincial intervention in the water board system. We return to this point at a later stage.

Returning to the question the arguments about public and private origins of the system both carry some weight. Fockema Andreae, the leading $20^{\text {th }}$ century legal historian on water management, argues that already in medieval time three basic types of water management institutions are to be distinguished: ${ }^{28}$

\footnotetext{
${ }^{28}$ S.J. Fockema Andreae, 3.
} 


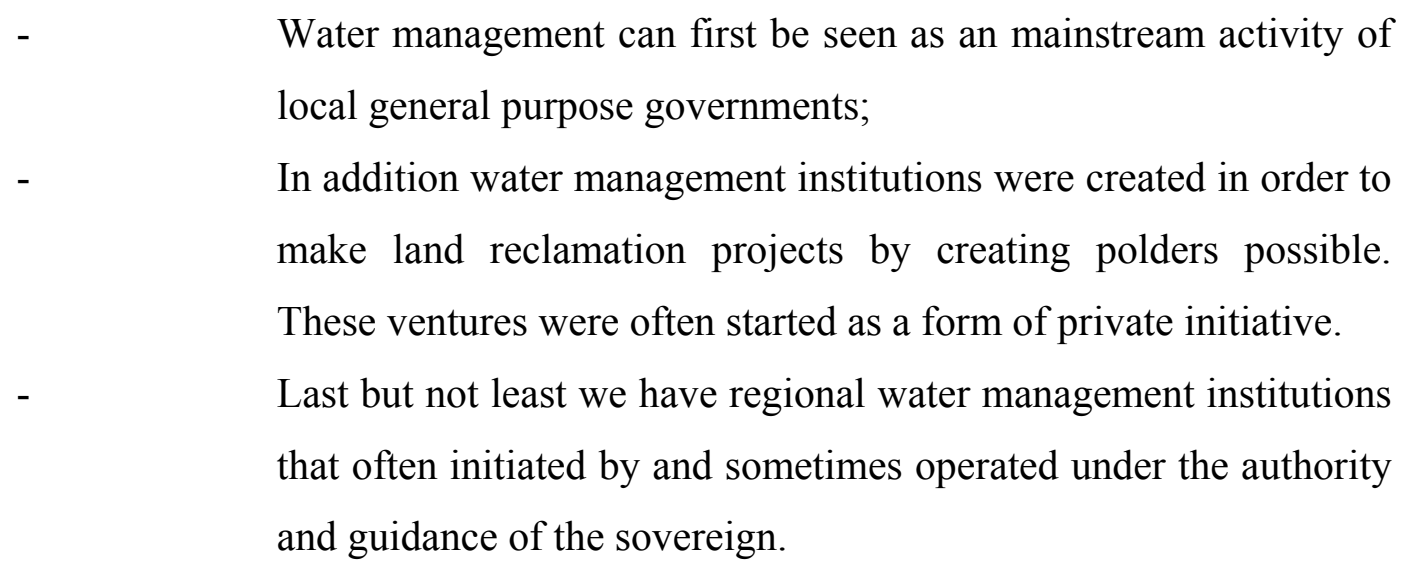

Local water management tasks in Holland and Utrecht were often separated from general administration. This institutional separation spread later to other parts of the country. ${ }^{29}$ This 'functionalization' of water management responsibilities was instigated by the proliferation of land reclamation projects. The polders required a separate water management regime given the specific hydraulic conditions of the area. ${ }^{30}$ The founding of the so-called polder bodies (in charge of the actual land reclamation and the ensuing water control tasks) was as said a private initiative. Public authorities endowed these organisations in the end with public authority. ${ }^{31}$ Later these polder bodies have been termed local water boards (waterschappen) but at the time a wide variety of names were used. Thus originally local water boards were purely a form of local functional government operated and financed by those people that were directly involved. Only later a more regional organised service dimension was added. This regional dimension to the water management became more prominent from the end of the $12^{\text {th }}$ century onwards when natural disasters in the form of storm floods increased.

Over time due to more advanced technological knowledge the effects of cultivation became even more noticeable. The effects of these calamities became all the more serious given the lowering of the ground level due to the cultivation projects mentioned earlier. Important in this respect were the advances made in wind mill

\footnotetext{
${ }^{29}$ This separation was finalized in fairly recent times with the general introduction of water boards in the eastern and southern provinces. In Holland the division of tasks was completed in the mid $19^{\text {th }}$ century with abolition of the 'ambachten' (forms of rural municipalities). See Van der Gouw, 31.

${ }^{30}$ It is argued that sometimes these polders received singular names to attract new settlers, for instance the village of Poortugal after Portugal and the village of Kockengen after Cocagne (the land of milk and honey). See Van de Ven, 45.

${ }^{31}$ S.J. Fockema Andreae, 4;
} 
technology. Using the new wind mills implies that more water could be pumped away from the wetlands. Given the fact the erosion of peat when made dehydrated, ground settlement increased a serious water management issues. In addition to the cutting of peat and thus the extension of the man made lakes the effects of incursions made by the sea and rivers caused an increased demand in the level of flood protection. At the same time local water management could have serious external effects on other local communities. These inter-local conflicts were mediated and adjudicated by use of the sovereign power. ${ }^{32}$ In the area of Holland the count initiated regional bodies for the implementation of water management tasks around $1200 .^{33}$ The intensification of supervision on (the establishment of) regional water boards were well continued in the Burgundian times and after during the era of the Dutch Republic (see below). Increasingly water management institutions as the water boards became integrated in the more general system of administration, whilst keeping their own separate identity. ${ }^{34}$

\section{The Dutch Republic}

By liberating themselves from their Habsburg rulers the Dutch at the end of the $16^{\text {th }}$ century also offset a movement towards more centralism. The Dutch Republic consisted of a confederation of semi sovereign provinces. Water management was not primarily a federal but a provincial and local task. The confederate arrangements made mediation of conflicts regarding water management at a supra provincial level exceedingly difficult as the history of water management during the $17^{\text {th }}$ and $18^{\text {th }}$ centuries did show. ${ }^{35}$ At first the provinces used their (newly regained) sovereign powers in a fairly limited way. That involvement pertained to giving permission for the implementation of large scale water management works (in the area of land reclamation and cultivation of untilled land) and formulating the necessary conditions to reduce the negative side effects for third parties.

\footnotetext{
${ }^{32}$ Van der Meer, Frits $M$ van der Meer, Water management in the Netherlands in the $19^{\text {th }}$ and $20^{\text {th }}$ centuries in: Jos C.N. Raadschelders, Fresh Water Management as Collective Action in Time: A MultiDimensional and Multi-Level Challenge of Governance in a Multi-Disciplinary Context, IOS press, 2004, forthcoming.

${ }^{33}$ See Dolfing and Bosch and Van der Ham, 25-27.

${ }^{34}$ B. Dolfing, Waterbeheeer Geregeld? PhD Leiden, 2000: 79.
} 
Dolfing ${ }^{36}$ has provided a micro analysis by studying the institutional development in comparative perspective between two main water boards in the province of Holland in the $17^{\text {th }}$ and $18^{\text {th }}$ century, providing a more in depth view into and thus an example of the supra-regional problems that water boards encountered at the time. The water boards Delfland and Rijnland were confronted with three problems that existed in each water board in a different intensity.

First, the dunes and sea-dikes needed increasing investments to prevent larger costs in the future. The annual maintenance of the dikes became less and less sufficient and the local appropriators or ingelanden demanded support from larger parts of the inhabitants protected by their dikes. The dunes already resulted under the provincial government but coordination with the water boards frustrated the summoning of responsibilities for sustainable CPR-management to the different institutional layers.

Second, the drainage in the very complex system of water levels and shared draining canals within and between the polders of not only Delfland and Rijnland but also between other water boards in the province of Holland and its neighbours was hard to manage, since binding decisions about certain drainage rights between water boards could not be made and even in cases where distribution of drainage rights succeeded there was no collective mechanism that could arrange supervision, let alone have true jurisdiction. Each individual windmill in Holland could start a "race-to-the bottom" by pumping water into the drainage canals above the agreed-upon common level.

Third, the lands protected by dikes and drained with canals consisted for large parts of peat that both the cities needed as fuel that helped the people in the countryside to increase their income and initially arranged for extra taxes for the water boards. The peat production resulted in ever enlarging inner lakes especially in Rijnland, between Leiden and Haarlem where now Schiphol Airport lays; creating uncontrollable water masses that threatened the maintenance of the inner-dikes and drainage-canals. This demanded more and more investments and maintenance of dikes and shores of lakes for which no taxes could be collected. To the contrary, because the level of taxation depended on the amount of land owned by the inhabitants, this peat production even limited the possibilities for taxation since land was lost to the lakes. In addition the

${ }^{36}$ ibid 
balanced administration of administrators and inhabitants - in good democratic traditionoften acquitted inhabitants from taxation. The burden on others in the countryside thus increased which could only stimulate peat production for its short-term financial advantages.

A number of disastrous floods in the $17^{\text {th }}$ and $18^{\text {th }}$ century spurred both the public, the cities and the administration of provinces and the Republic to take a closer look at the functioning of the water boards. The up-scaling of the water boards and the increasing voice for the hoofdingelanden and cities in the water management system had been the result, as well as that the technical expertise of maintainers became an issue, since the complexity and intensity of the water management dilemmas increased. An example is the request by Delfland to the neighbouring province of Zeeland to help with dunereconstruction. Discussions with neighbouring water boards about the shared sea-dikes and shared drainage canals in the north and east of its territory, forged the administration of Rijnland to claim unity while requesting subsidies by the Province for an extra water exit through Katwijk's dunes in the west and a request to support for turning the immense Haarlemmer-lake into a polder (Danner, 1993). The cities of Holland had an increasing influence in the administration of the water boards and in the $18^{\text {th }}$ century proved to have blocking power in the water boards vis-à-vis the inhabitants of the countryside, the ingelanden. The water board Rijnland was confronted with a stalemate between the cities of Leiden, Haarlem -with their own interests- and the other administrators in the hoogheemraadschappen.

The problems were not only confined to the sea or lakes. In addition the situation of the river flows was giving Holland and other provinces the necessary concerns. The division of water over the different branches of the Rhine had become imbalanced due to up stream canalisation works. As a consequence of the increased water volume in some of the branches of the Rhine, dikes were endangered. Due to the highly prized provincial sovereignty inter-provincial co-operation to solve the existing problems proved to be exceedingly difficult. Although an inter-provincial committee was installed no direct 
positive results were reached. ${ }^{37}$ In order to tackle the problem Holland appointed an inspector-general of 's lands Rivieren (rivers of the country) for its own area in $1753 .{ }^{38}$ Similar to other parts of the administrative system the federal institutions were inadequate to handle the supra-regional water management tasks. In the end however a solution was found for the river issue. In 1771 a treaty was sealed between the King of Prussia and the provinces of Gelderland and Holland after negotiations of 22 years. ${ }^{39}$ This treaty can be seen as an early international treaty for co-operation on water management.

Concluding, the central elements of the institutional framework governing the Dutch system of water management system originated in medieval times and remained in force during the time of the Republic. Quite early during these formative years the actors relevant today came to the limelight. A variety of water boards, local governments, (groups of) private citizens, sovereign provinces and to some degree federative structures got their part in this compound task. With these actors also a complex system of intergovernmental relations came into existence. These intergovernmental relations intensified during the course of history as the effects of interdependencies in water management became more and more manifest. In order to deal with these external effects and the ensuing conflicts, mediation and supervision was imperative. Nevertheless the federative structures were lacking in effectiveness.

The Dutch revolt against King Phillip of Spain effectively ended the development towards a more centralized authority. As said earlier within the constitutional structure of the Republic the emphasis was laid on the autonomy of the participating provinces. Introducing reform was exceedingly difficult given the ossified decision making structures. ${ }^{40}$ Water management was considered belonging to the autonomy of the provinces and the provinces guarded their sovereignty with much vigour. The weak institutional structure of the Republic proved to be (as in many other task areas)

\footnotetext{
${ }^{37}$ Fockema Andreae, 20

${ }^{38}$ H.A.M.C. Dibbits, Nederland waterland: een historisch-technisch overzicht, Utrecht: $1950153 \mathrm{ff}$.

${ }^{39}$ Dibbits, 158. J.L. van der Gouw, De voorgeschiedenis van de provinciale waterstaat in Zuid-Holland, in: Honderd jaar provinciale waterstaat in Zuid-Holland. Enige opstellen over de geschiedenis, 'sGravenhage: 1975, 17-18.

${ }^{40}$ See Frits M. van der Meer, Crises and administrative innovation in The Netherlands, in: Yearbook of European Administrative history, Baden-Baden: Nomos, 1995, 187-222.
} 
detrimental to an adequate level of water management. Towards the end of the $18^{\text {th }}$ century this problem became more widely perceived. But only through the demise of the Republic as a consequence of the French invasion in 1795 the door was opened to a new central government involvement.

\section{Modernization of the system}

The importance of the French era as a defining period in Dutch history is well documented in Dutch historiography. ${ }^{41}$ 0n the $16^{\text {th }}$ of May 1795 the Batavian Republic was proclaimed when the last stadhouder had fled to England leaving the country to the control of the revolutionaries (called patriots) supported by French troops. The term French era, used above, is a little bit confusing as the period of 1795 to 1813 contained different political regimes that produced a variety of constitutional designs. In effect to a certain extent the entirety of the French era can be seen as a time packed with political and constitutional experiments. Under pressure of Napoleon the Kingdom Holland was created in 1806 and finally Holland was absorbed into the French Napoleonic Empire in 1810. For our purposes the Batavian Republic is of prime importance. Politicians in the Batavian Republic fought out intense battles over the question whether the system of government should be predominantly centralised or have a federalised format. Although the original lofty ambitions of the founding fathers of the Batavian Republic were more than often not accomplished finally in 1798 a unitary state was founded in 1798 after a coup d'état supported by the French. As an outcome of this revolt, a powerful centre did emerge facilitated by government departments.

During the later part of the French era a task division between the main actors (central government, the provinces and the water boards) emerged that is still more or less in operation today. ${ }^{42}$ The constitutional arrangements of the French era and later the constitutions of the Kingdom of the Netherlands (1814 and 1815) decreed that central government was to have the final responsibility for and supervision on water

${ }^{41}$ See for a discussion Frits M. van der Meer, Jos C.N. Raadschelders, Between restauration and consolidation. The Napoleonic model of administration in the Netherlands 1795-1990, in: Bernd Wunder (ed.), The Napoleonic model of government, Brussels: IIAS, 1995, 199-222.

${ }^{42}$ W.L. Kloosterman, Het waterstaatsbeheer in de Bataafs-Franse tijd: 1795-1813, in: Toonen en Raadschelders: 1993, 93-106. 
management issues. In this sense national politics and administration was to have the 'supreme' control on water management issues. By this method deadlock situationsdetrimental to the solution of supra-regional water management problems during the time of the Republic- could be avoided. Apart from supervision and control issues central government was in charge of water management projects and works considered in the national (defined as general) interest and/or paid from the central government budgets. Although central government became the major player the involvement of provinces and water boards remained crucial. ${ }^{43}$

\section{Emerging intergovernmental dimension of CPR management}

The conception of the Kingdom of the Netherlands after the fall of Napoleon provided a new stimulus to an increasingly active central government in the area of water management. Working along the lines of the administration during the French era the central aim of the new ruler King William I (the son of the last Stadholder) was to renew and reinvigorate the country both politically and economically. The downfall of the Republic was not only generally attributed to its failing political and institutional structures but also to a decline in economic prosperity. According to popular perception the once thriving Dutch economy in $17^{\text {th }}$ century (styled the golden century) went into a long period of recession due to a weakening entrepreneurial attitude of the $18^{\text {th }}$ century business classes. According to William it was necessary to improve the physical infrastructure in order to stimulate economic prosperity. Reclamation of land, streamlining of rivers and digging canals were considered of the utmost importance. The new King was eager not to repeat the same mistakes as his $18^{\text {th }}$ century ancestors by abstaining from the use of available instruments of power. These instruments were handed to him readily by a population (in the Northern half of the country) that had grown weary of the democratic experiments during the previous years. In order to achieve his objectives the French inheritance came quite in hand. This applied in particular to the government departments that could and did support his preferred

\footnotetext{
${ }^{43}$ In 1810 responding to serious floods in 1804 and 1809 a Dijkwet (Act on dikes) was enacted. This law aimed to set up a central authority supervising dikes and other water works. The centralised approach of the law caused much resistance with the existing water boards. The Dijkwet was suspended in 1813 and repealed in 1835. See Kloosterman, 99-102.
} 
paternalistic style of governance. One of these departments was involved with water management. In 1798 as part of the new centralised constitutional arrangement a department for Inwendige policie en toezigt op de staat van dijken, wegen en wateren (Internal affairs, public works and water management) was created. Only later during the century (1877) internal affairs and public works were institutionally separated and from 1906 public works was made into a separate department. This situation still endures

In order to implement the water management tasks of central government an agency for public works (Rijkswaterstaat) was also founded in 1798. This agency was later to become one of most foremost players in Dutch water management. During the $19^{\text {th }}$ century Rijkswaterstaat gradually developed into a crucial factor in Dutch water management. Its role was to provide and develop the technical design of water management works and supervise the public tendering of projects to the private sector and the supervision on these enterprises while working on the construction. Although at first external advisors and advisory bodies were competing with Rijkswaterstaat in the area of project design they slowly obtained a monopoly in this field due to their enormous technical expertise towards the end of the $19^{\text {th }}$ century. That expertise and the professional standing were greatly enhanced by the foundation of the Koninklijke Academie voor Burgerlijke Ingenieurs (the Royal academy for civil engineers) in 1842 in Delft. ${ }^{44}$ For a considerable time Rijkswaterstaat dominated civil engineering in the Netherlands. Only from the first decades of the $20^{\text {th }}$ century the number of civil engineers employed in the private sector increased substantially.

Like in other sectors the central government involvement in water management issues grew during the $19^{\text {th }}$ and $20^{\text {th }}$ century. That involvement both regarded taking a responsibility for managing and taking a design role for the Dutch water management and executing highly visible large scale public works.

\footnotetext{
${ }^{44}$ Harry Lintsen, Ingenieurs in Nederland in de negentiende eeuw. Een streven naar macht en erkenning, 's-Gravenhage: 1980.
} 
Although the provinces decreased in importance after 1795 they remained to play an important part in water management. However since the constitutional arrangements of 1795 they were firmly placed within the framework of the central government guidelines. The main provincial tasks consisted of the supervision of the water boards and the execution of provincial water management works. ${ }^{45}$ Until around 1848, provincial administration (in the area of water management) worked under the direction of Rijkswaterstaat. In the constitution of 1815 it was decided that central government could decide what water management projects should be carried out and administered by central government, the provinces, the municipalities and the water boards. ${ }^{46}$ In 1819 a transfer of previous central government tasks was made to the provinces. The provinces were expected to pay for the costs. These tasks also included the supervision on sea and river dikes. ${ }^{47}$ The reason for this transfer was that the representatives of the southern provinces (present day Belgium) considered the financial expenditure on water management by central government to high given the fact that mainly the northern part of the country profited from the execution of these tasks by central government. A number of engineers of Rijkswaterstaat were included in the transfer. However from an organisational point of view they remained part of the organisation of Rijkswaterstaat. This complex situation led to a number of serious conflicts between Rijkswaterstaat and the provincial governments. The first breakthrough came with the constitutional change of 1848 .

\section{Contemporary constitutional structure and development}

The constitution of 1848 opened the way for the creation of separate provincial agencies. It took however a fairly long time before the first provincial agency was created (1860). The province of Zeeland was the last (1881). The decentralised central government tasks were taken back in 1876. The new provincial organisations were in charge of the building and maintenance of provincial roads, waterways, (and the operation of) bridges and locks. Before World War II the most important area of growth was the building and maintenance of provincial roads. After the war the provincial boards were reorganised

\footnotetext{
${ }^{45}$ Van de Ven, 174-175.

46 Van der Gouw, 21-22.

${ }^{47}$ Bosch and Van der Ham, 50-51.
} 
and made into agencies charged with environmental affairs, roads and water management.

The provinces have had a long history of involvement with the water boards and that involvement only increased after 1798. As argued above during the French times the water boards were more or less left untouched apart from the effects of the short-lived Dijkwet. A more important consequence was the replacement of old forms of local government by municipalities. The creation of municipalities meant in practice that general administrative tasks were removed from these old local governments (called ambachten, marken, gerechten grietenijen etc). What however remained involved water management tasks and they became in fact water boards. As mentioned before they only disappeared towards the middle of the $19^{\text {th }}$ century by provincial action. During the $19^{\text {th }}$ century the provincial involvement with water boards increased and was formalised. In the constitution of 1848 the right and duty to approve the water board codes and the responsibility for the creation and the abolition of water boards were made responsibility of the provinces. These rights and duties were further elaborated in the Provincial Act of 1850.

Water boards remained however in a practical way the central institution regarding local and regional water management. Although from time to time its existence was under discussion its position has been reinforced. A first defining moment came in the middle of the $19^{\text {th }}$ century. With the constitutional reform of 1848 the autonomy of the water boards was recognised.

The current name for 'water boards' - waterschappen - dates from the drafting of the constitution of $1848 .{ }^{48}$ Under this term a variety of different institutions of different size, tasks and accountability structures are hidden. The provincial regulatory powers led to a certain degree of standardization. During the $19^{\text {th }}$ and early $20^{\text {th }}$ century the main concerns of water boards were water quantity control and the protection against sea and rivers. Which tasks were taken up differed according to the water board in question. Even two different water boards could operate in the same area but having different tasks. The main criterion for a geographical demarcation of water board remained the particular

\footnotetext{
${ }^{48}$ S.J. Fockema Andreae, 29.
} 
catchments area. In practice this meant that he criterion of functionality (in terms of water management) was dominant. Given the fact that water management areas did differ according to geographical conditions, we could find very large and small water boards at the same time. In the aftermath of the 1953 flood the system of water boards has been fundamentally overhauled. Water boards have been responsible for managing their local water concerns. That geographical scale was considered to small given the needed technical expertise and financial strength. In many cases the dikes administered by the (smaller) water boards were in serious state of neglect.

After the Great Flooding Disaster of 1953 - generally considered one of the historical National Disasters in the Netherlands - a new temporary agency of Rijkswaterstaat was set up by central government using an emergency legislation in order to make the necessary repairs of the dikes. Parliament did not like this kind of centralism and only agreed with the emergency legislation with much reluctance. Nevertheless central government, most provinces and water boards did agree on the necessity of a concentration of water boards. In Zuid-Holland and Noord-Brabant this amalgamation was speedily executed. In Zeeland - the areas most severely hit by the 1953 disaster - the process took more time and pain. ${ }^{49}$

The effects of the 1953 Flood on the water board system were more extensive than merely leading to a reduction of the number of these organisations. Although a majority in Parliament was in favour of the water board system a serious enquiry was demanded in the working of the system. After some earlier abortive attempts in 1969 a committee was installed (styled diepdelvers or in English 'deep diggers'). In 1974 this committee reported that the water boards should be operating on a regional instead of the old local scale. Government in 1977 adopted the advice of this committee. An additional factor leading to this regional approach was the need for larger entities as provinces increasingly wanted to decentralise the execution of the maintenance of surface water quality to the water boards. This particular task demanded a much larger geographical scale than most water boards previously had.

49 Bosch and Van der Ham, 191. 
Finally the new position of the water boards were legally translated in a constitutional provision in 1984, the Water management act of 1990 (Wet op de Waterhuishouding, the Water Board Act of 1992 (Waterschapswet) and the Act on the dikes 1995 (Wet op de Waterkeringen). An additional consequence of the modernisation of the water boards was that the system of accountability was democratised by simplifying the political structures and extending the franchise.

\section{Challenges and adaptations for the new millennium}

Concluding over the last decennia the number of water boards has been reduced from around 2500 to around 26. Coinciding with these profound merger programs it is important to observe that the subsequent political, professional attention for the system, perhaps indirectly triggered by the attention for the water board system in the aftermath of the Great Flooding of 1953, had contributed a lot to a redefinition and re-evaluation of the overall water management system and policies of which the water board system constituted only a part, albeit an important one. The reforms would be ill perceived as a retarded but solidified reaction to the findings and conclusions in the aftermath of the 1953 Flooding only. The regained attention to the system in the process was substantiated by various other challenges, some internal, classical ones just waiting to be rediscovered, some external, new and unexpected one's caused by - long time disputed climatologically changes (global heating; rising of sea levels; shortages of fresh water) or by a newly emerging European order with at least many indirect and over time also increasingly direct effects and consequences for the Dutch water management system as a whole, and the water board system in particular.

This is not the place nor do we have the space to sum up all these developments in its complex detail. At the end of the millennium challenges which the water boards were facing may be phrased four broad categories. ${ }^{50}$

First, water boards were encountering substantial legitimatization problems. The aim of striving for functional legitimization - costumer orientation in service delivery increasingly turned out not to be a fruit bearing strategy. Water boards increasingly encountered institutional and procedural legitimatization issues, propelled and

\footnotetext{
${ }^{50} \mathrm{cf}$ Toonen, Th, et. al., Een bestuursschouw van het waterschap, Utrecht, Februari 2000
} 
compounded by the fact that the relatively recently introduced elections of the population category in the general board resulted in low voter turnout, which made 'water board democracy' vulnerable as the laughing stock for other governments and in the media ('lower even than the elections for European parliament...'). It was also clear that they were struggling precisely in the area of keeping the water board in tact as a community based form of water management. The managerial focus which dominated water board modernisation throughout the 1990's did not pay much attention - nor attach much value - to this historical institutional feature of the water board as an institutional entity.

Secondly, water boards had gotten themselves into an effort to broaden the scope and ambitions of their activities or even mission. Ever since the 1970s environmental considerations increasingly had to be taken into consideration in water management policies. This required sometimes substantial investments in infrastructure, protection and cleaning up. Some threatening situations with river floods and near disasters with river dikes near densely populated areas, made the population and therefore the political system keenly aware again of the power and danger of water in the Dutch context. Apart from lacking dyke maintenance and increased rainfall, causes were found to be 'manmade': straightening of rivers or building residential areas and industrial sites in river beds. Policymakers became aware, again, that the natural water system had to be a 'guiding principle' in physical and spatial planning, currently amounting to a national policy to create 'Space for the River' and actually turn land again into wetlands or lakes. With environmental and spatial planning entering the considerations, man advocated to bring the activities into the water boards system or even turn water boards into regional '(natural) environment boards. This would have broadened and changed the character of the water board, and at least brought them in a sometimes rivalling position to provinces. Also they had to pay more attention to municipal government policy, which play a pivotal role in Dutch spatial planning, a relation that hitherto was rather neglected by both governments. In whatever organisational strategy it became clear that the array of considerations and therefore competencies to be taken into account had to be broadened, with all kinds of consequences for the composition and build up of the organisational apparatus of the water boards. In the meantime, this situation has lead to a complete redesign of major (national) water and water related policies, together with a whole new 
system of intergovernmental negotiations and planning. Recently, a "National Water Agreement" has been signed by all institutional (government) parties involved, basically introducing a new systems of intergovernmental negotiation into the overall water management system of the Netherlands, in which the special responsibility and 'relative autonomy' of water boards versus other levels of government has recently been reconfirmed.

Thirdly, many water boards historically had included water production, purification and water supply for the citizens and industries of the region into their activities, next to the responsibility for water containment. The latter activities are referred to as the 'water system' responsibilities. The water production activities are referred to as 'water chain activities'. They needed to be understood, not as a territory based activity, but as a function in a much broader process - 'chain management' - of water cleaning, purification and supply. The two activities are often interrelated, reason for the water board system to eventually and - often after long debates - almost universally opt for an 'all in water board' where the two functions were combined. This had already lead to a first wave of mergers in the 1980s in areas were water production firms and 'water quantity boards' were still separated. The 'all in water board' today is the standard model, introducing a dual rationality into the heart of the water board system. Water production and water quality require a much more business like and economic approach, sometimes amounting to large scale investments and 'market oriented' strategies. This puts infrastructural and financial capital in the centre of the attention. The water system management is more natural, environmentally, physically and socially oriented in nature. Water system management is the domain of the - less visible and more difficult to quantify - social capital. The two forms of capital are not always easy to reconcile, at regular times (and often implicitly) leading to questions which rationality - 'water chain' or 'water system' - should prevail, placing heavy demands on the quality of the management of water boards themselves.

Fourth, the ongoing European integration process has been forecasting shadows to the Dutch water management system for some time to come, without necessarily amounting to clear cut conclusions. Recent attention is concentrated on the consequences of the implementation and execution of various EU Environmental and Water directives 
negotiated among the member states, by 2015. There are many European developments indirectly affecting the water management and water board system of the Netherlands. European integration has in itself contributed to a renewed awareness that the Netherlands lies in the mouth of a delta system of great European rivers, with all consequences of decisions affecting water quality and water quantity taken elsewhere, across national borders. European environmental policies - as part of global (Kyoto) agreements - have many different impacts on the nature of water system management and national preservation or other environmental considerations in various Dutch regions. Debates on 'marketization' or privatisation of water production - in other European countries the 'water production chain' is regulated by government, but largely operated by private and commercial enterprises - clearly have affected already the debate on the 'efficiency' of Dutch water boards in this respect. It is only a matter of time and questions of (European) 'level playing field' and (warranted or unwarranted) 'government support' will be raised in situations where water system and water production are as closely integrated as they are in the case of the Dutch water boards. There is not yet a 'European model' developing here, but the Dutch water boards are a rather unique institutional 'hybrid' structure in a European context, which - despite applying principles of subsidiarity - might not survive European 'harmonisation' on the basis of a government versus market dichotomy.

These various challenges, each in there own way pointed into the direction of scale enlargement, at least the reduction of the number of participants involved in the overall management of the increasingly integrated challenges facing the water board system as a whole. The professionalization of the governance and (business)management of water boards system, the capital intensive environmental and water production strategies, requiring large scale investments, the integration and coordination of - sometimes competing - neighbouring small scale water boards into regional territorial units capable of handling natural river and drainage basins - the natural territorial entity of the current water board system - in an integrated manner, the linking up with other units and levels of government, the fusion of 'chain' and 'system' functions as an organisational consolidation strategy in an emerging European space, provided ample 
rational to a generally supported and sometimes even water board initiated merger process, dramatically changing at least the historical face of the 'patched' Dutch water board system in recent years. The fact that they are facing new challenges and witness substantial adaptations is something the Dutch water boards have 'in common' with many other Commons in the new millennium. ${ }^{51}$ But have these adaptations not affected the nature of water boards as institutions for CPR governance and management?

\section{Modernisation and reform: 'Institutional Resilience' or 'Historical Break'?}

In the Dutch context, many wonder whether the functional concept of the water board still fits in the contemporary 'spirit of the times', with a generally acclaimed need to 'integrate' government in the background. One might assert that the functional nature of the water board isn't contrary to the spirit of the times, but precedes it. The 'general' party politics is in crisis in almost all political and institutional analyses. On all sides there are indications that the interest of citizens for general politics is decreasing. In contrast, the modern citizen is highly interested in concrete matters, in the interests that personally affect him. He shows increasingly participating behaviour in this aspect. In different scenarios functional administration based on concrete interests has prospects. There are a lot of bodies of functional administration in the Dutch governmental constellation, but in a lot of other countries too (and also on the level of the European Union). The water board is a nice construction within this context. The parties directly involved can be precisely identified and be involved in decisions which touch them directly. Possibly there is still some ground to cover for the 'general public' as a party involved.

With a lot of other functional bodies, questions can be raised on their democratic legitimisation, especially when it comes to a lot of independent administrative bodies (NGO's). In the case of the water boards this is taken care of organically and is deeply rooted within the constitution. But it is precisely this characteristic of water boards, which runs the risk of becoming eroded in the process. The water boards have, understandingly, devoted much time and energy to the reform process as such,

\footnotetext{
${ }^{51}$ Nives Dolsak, Elinor Ostrom (eds), The Commons in the New Millennium: challnges and adaptations, Cambridge (Mass), 2003
} 
organisational, infrastructural, demarcation and financial issues, somewhat neglecting the governance, particularly the self-stakeholder-governance dimension of their institutional past. Water boards themselves have treated the issue in a rather opportunistic way. The triplet - interest, financial contribution, participation - has often been heralded in the recent political debate, but mostly in an effort to establish some mythical safeguard its independent right to taxation.

The interest community based character of its governance structure has subsequently been treated rather opportunistically, by some for financial reasons and by others simply by neglect. Their own institutional history suggests an adequate representation of affected interests to be of crucial importance for the efficiency, legitimacy and resilience of the water board as CPR management form in the Dutch - and increasingly European - context. Looking after interests and handling conflicts are crucial characterisations of successful commons-government. Additionally, one can see in contemporary society a general tendency to involve the stakeholders with the administration of a government, business or social organisation. The water boards are in fact ages ahead of this development, what can lead in some aspects to a dialectics of progress.

The business administration stakeholder notion however, is quite broad and administratively free of cost. Because of this it is of little guidance for the kinds of interests that deserve representation in a pressure group-democracy like the water board. Every individual and more or less involved person or institution seems to be considered as being a 'stakeholder'. The consequence of this is that on the whole a very diffuse collection of organisations is seen as 'parties involved'. For such a collection of 'stakeholders' an advising role for the general management is a nice prize: 'a consulting model' with the CEO's of the water boards in the driving seat is all what seems to remain from a once firmly embedded co-decision structure of the interest parties in the governance and management of the water board. The legitimisation, controlling and also conflict regulating effect of the advisory stakeholder council construction is minimal. The water boards should think again on the precise definition of the categorical interests. It is not possible to end this discussion inside the scope of this paper. The decision of the 
government however, still offers a starting point for modernisation of a more categorical and therefore more professional 'stakeholder' representation.

It is also of some importance to note, that the 'inhabitants' count as a party involved for the water boards. Under the current developments this category is becoming of relatively more importance to most types of water boards. Many are located in densely populated areas. Also in a more limited sense, 'community based governance' seems to remain an important dimension of CPR water management in the Netherlands. Often, however, the inhabitants are presented as representatives of the "general interest' in the water board, next to the 'functional interests'. It is overlooked that in the design of the system it are the municipal, provincial and national governments which supposedly represent 'the general (local, regional and national) interest' and that these have been entrusted with all kind of tools to externally represent these 'general interests' form and substance in their contextual meaning to the water boards, through the system of external administrative and intergovernmental relations with state, provinces and local authorities. The point is that inhabitants (citizens, residents) also have a clear functional interest in the water boards that does not always run parallel to the interests of other parties involved. Besides them one can think of company's, farmers and managers of nature reserves (stewardship organisations). 'Inhabitants' of the water board are a special stakeholder category and should institutionally be represented as such.

The water boards got themselves caught in a debate with only two alternatives and did not do itself a favour neglecting the Third Way which there history actually represents. Water boards seem to have gone along with the discourse in the national debate which forces them to make a choice between either a line system or a person system in representing citizens as stakeholder category in the water board system. The person system has been tried over the past few years and quickly became put aside as unusable because of scale enlargements and lead to undesirable results and side effects. Due to the scale enlargements, the amount of candidates who can be chosen has become so large, that a lot of voters don't know who to vote for. This does not contribute to a large turnout, or to the status of the people elected. In addition, people who do vote, choose a candidate quite randomly (the so called 'upper-left effect'). In effect, in some water boards, various 
other interest categories - most notably the agricultural sector - where able to capture the 'inhabitants-category' creating a clear overrepresentation of their interests in specific water boards, thus giving rise to the putting down of water boards as 'farmer republics'.

A line system, as the alternative, can lead to the situation that existing parties either under their own name or undercover- will dominate the water board system. The risk involved is that the water board elections will be a shadow of the national relations. Motives to vote for a party will mainly relate to the themes which play a role in the national politics, not in the specific water management system the specific board in question is supposed to 'govern'. On top of this the risk once again occurs that the water board will resemble some kind of second province. This would all contribute to the erosion of their 'special district status' what could eventually lead to a clear call to abolish the water boards. As a matter of fact, it is safe to say that the 'generalisation' of water board elections by introducing a line system is part of a more than barely overt strategy of in provincial politics. The integration of water boards into the provincial organisation - with all the consequences for them as independent CPR governance and management systems on the long run - is desired feature by many provincial political representative - as one would theoretically expect in a 'rational' system.

The institutional design problem is that the water boards have neglected what amalgamated local authorities often are trying to do: to take care or soften the unfavourable effects that are visible next to the benefits of scale enlargement by intramunicipal decentralisation. Not to undo the scale enlargement by another way, but to newly organise the involvement of the citizens in a larger institutional context, or at to least try to do so. It is important to observe that the actual operation of the management side of the water boards, particularly in the sphere of the water-system domain, is generally still relatively small scale - territory and problem oriented and in close interactive cooperation with interest involved. Water boards could make more use of territorial commissions to link the governance structure to this management structure and to enlarge the involvement of the citizens on the governance side. These territorial commissions could be directly elected. The representation of the inhabitants in the general council (joined meeting) could then be elected by (and from) these territorial 
commissions. Direct and indirect elections can be combined this way. It would introduce a kind of functional 'implementation federalism' into the governance structure of water boards representing the specific parties, practically and operationally involved instead dragging considerations and a representation of ideologically driven 'high politics' into the governance arena, also blurring the distinction of water board interest politics with provincial (and municipal) general representation politics. The most important negative side effects of the person system (a large amount of candidates just as the unfamiliarity with the candidates) can be taken away and the hitherto specific nature of water board politics as a way of conflict resolution could be saved. Instead of linking up with the party system of the representative democracy side of Dutch government, the classical water board notion of the interest group-democracy points for an institutional alliance into a different direction. The water boards should form an alliance with certified societal - 'civil society' - third party organizations. Both old and new NGO's have proven themselves to be able to mobilize significant parts of the civil society for common interests and purposes. They can help water boards to prove the future vitality of an interest group style of democracy.

\section{Conclusion}

Water containment, water quantity and water quality are - certainly in The Netherlands from various angles to be seen as Commons. The water board is historically the Dutch institutional answer to the administrative problems that come with those. It is a form of Common Pool Resource (CPR) management which has developed throughout the ages. The 'water board' as an institution has strongly evolved in the course of time. The water board and water management are currently going through a new phase of strong institutional development under the influence of international ecological economic and technological factors. The scale enlargement which took place in the last decades - from over 2500 to just 26 - has no precedent in the history of the water boards - nor elsewhere in the system of Dutch home affairs. It is highly likely that classical institutional questions will have to be re-answered in the Dutch common pool resource (water) management. Classical principles should be rediscovered if not reinvented. 
The water board is in fact a classical and historical example of the 'community based governance' which is internationally being recommended so strongly right now as the right direction for institutional development for common pool resource management. We conclude that the recent developments pose a threat to this essential feature of the water board system. The scale enlargement is posing complex questions regarding the issue of functional interest representation, not in the least where the interest of the citizen as member of the water board governance structure are concerned. There is, however, room for reflection. Water boards as institutional commons are man-made. There are several ways to reinvent and revitalise the functional interest democracy in the context of the larger territorial, infrastructural and economic scale at which water boards will have to operate in the future due to increased functional and international scale-requirements.

The recent scale enlargement of the Dutch water boards might quite well turn out to be a strategic move to survive in an increasingly international and particularly European future. History might later identify this break with a 'small scale'-tradition as an historical act exemplifying the resilience of water boards in remaining robust institutions for CPR water management in an increasingly European and global development. As in any substantial reform and modernisation process some essential institutional features might get lost in the battle and process, effectively changing the institutional nature of the water board as a form of water management.

We have particularly pointed at the vulnerability in terms of - remaining - an interest and community based form of CPR governance. Our historical analysis of the long term process mounting up to the present day reforms suggest that it is not only necessary to pay attention to the 'internal operation' of this CPR management form in relation to its inhabitants and other 'stakeholders'. The external, intergovernmental dimension has consistently played a key role in influencing - threatening, facilitating, initiating - the resilience of the Dutch water boards. Our historical analyses indicates that features of the intergovernmental system - in addition to internal structure and characteristics of water boards - have played a key and on many historical junctions and occasions for the resilience of the water board system critical role to ensure a robust and sustained performance of the system - next to its mere 'survival'. 
From the intergovernmental perspective, the future of the water board in the Dutch context, next to the sustained institutionalisation of the principle of community based governance, depends on the quality of the general (municipal, provincial, and national) democracy, to fence off and politically interpret the specific and constitutionally assigned interests. The core business and mission of the water board is clear and of strategic importance to the Dutch society. The functional, purposeful nature of the water board implies that one may selectively activate complex networks in dealing with complex matters and perhaps also be selectively alert to strategic 'passionate interests'. Other governments should 'check and balance' and externally correct any possible onesidedness as a result of such 'institutionalised biases in the functioning of water boards. They do have access and the legal and political means to do so. The water board can and has to pay attention to other related or affected tasks and interests than water management in the strict sense only. But the water board is not created for the execution of those tasks. The closer the water board can stay to its core business; the better off it is - in institutional terms. If the water board starts taking more tasks on itself, and broaden itself to for example environmental policy or physical planning, it would start to resemble a body of general government more and more. This will potentially damage the selectivity and alertness of it. When this development occurs, this would mean the downfall of the water board system in the long run. When the water board will develop itself to some kind of second province, the issue of merging province with water boards will be raised.

To put it different: from a resilience perspective the water board with a specific set of tasks and needs a well functioning general government next to, so it can focus it's efforts completely on it's core business. In the context of the current analysis, next to the internal governance structure, three factors are of importance to the continued institutional development of the Waterschappen as a CPR governance unit. Particularly the relation to the province is of crucial importance in the current state of development. The relational affairs between the province and the water board should be structured by three main principles. 
First, the province is playing a role - or should play a role - in the further construction and composition of the water board, for example on it's management structure. This way the water board can produce tailor made solutions regionally and adjust the management structure to the regional and social-economic context within a general legal framework. Possibly this is also valid for other questions of arrangement in relation to the water board.

Second, from a policy perspective the province establishes the broader ecological, social-economic, spatial, environmental policy framework wherein the water board - and their related organisational network - normatively need to operate in conducting their functions as CPR water management systems. A separation of policymaking (by provinces) and policy execution (by water boards) - which is a popular conception in the current debate - is meaningless. Strategy is defined preferably by dialogue. Both of the governments involved should be focusing on the execution of policy and have a focus on 'getting things done'. 'Execution' shouldn't be taken as a technical or instrumental activity either, but as a highly normative and political matter in which many further operational policy choices have to be made in which sometimes huge specific interests are at stake. It is the task of the provinces to determine the policy in its own territorially defined region and they have the discretion within the legal framework to do so. Furthermore, this general purpose government task is done best when the executive tasks are placed at a certain distance to make sure that daily worries can be exchanged for a strategic, be it hopefully practical vision. It is important to remove the relation between provinces and the water boards from the 'shafts' or 'pillars' (sectors) of water management and environmental policy. What is needed is the embeddedness of water management in the economical and spatial strategy and in the broader governmental relations between Europe, national government and state provinces and local authorities. The last ones shall be addressed on their role in the water management more often.

Third, an ever more important and independent position is occupied within this whole relation and the agreements in the period after the National Water Pact by supervision. The supervision requires the attention within the relation between the province and a water board. Connected to the functional nature of the water board, one should put forward the notion that supervision is essential in the execution of tasks within 
a functional government. The water board benefits from a correct form of integral and independent supervision, not only to verify if the water board is functioning properly in its technical 'water specific' requirements - rather the domain of internal quality care systems - but also to make sure that an integral form of synchronization and exchange with developments and findings with other policy sectors comes into existence. Also because of the scale enlargement in the water boards system, it is mostly the province which is now the primary supervisor of the water boards.

Supervision is increasingly recognised again as an independent function of transparent (European) government and governance. It should be 'horizontal', 'proportional' and 'integral. It connects as much as possible to own information and quality care systems - and partially shapes them - of those being supervised. It is mostly focused on administrative responsibilities, not on operational execution. It is broad in scope. Not only water management and environmental norms, but also for example 'safety', 'administrative costs', 'integral government' and 'community based governance' could play a large role in the auditing protocols of the future. Water boards are benefiting from a good form of supervision by the province. In contrary to water boards, good oversight or 'supervision' by the province is a key factor in the Dutch intergovernmental system that - like many other institutional features - has turn out not to able to sustain itself as a resilient institution. Dutch society has witnessed the consequences over the last few years in many areas, perhaps least so in the area of water management. The institution of administrative oversight - crucial to any resilient form CPR management is now in the process to reinvent itself in the Netherlands. 